\title{
Pedigree selection in sesame under artificial infection of Fusarium oxysporum f. sp. sesami
}

\author{
Mahdy, E.E. ${ }^{1 *}$, A.A. El- Shimy ${ }^{2}$, M.A. Sayed ${ }^{1}$, Amer F. Mahmoud ${ }^{3}$ and Aya Salah $^{2}$ \\ ${ }^{I}$ Department of Agronomy, Faculty of Agriculture, Assiut University, Assiut, Egypt \\ ${ }^{2}$ Agriculture Research Center, Oil Crops Division, Egypt. \\ ${ }^{3}$ Department of Plant Pathology, Faculty of Agriculture, Assiut University, Assiut, Egypt
}

\begin{abstract}
Fusarium is one of the most dangerous fungal diseases that cause great loss of the sesame yield worldwide. The present work aimed to improve tolerance and/or resistance to Fusarium through two cycles of pedigree selection on sesame population for eight selection criteria started in the $\mathrm{F}_{3}$-generation. Genotypic coefficient of variability in the $\mathrm{F}_{3}$ varied from $4.34 \%$ for days to $50 \%$ flowering to $38.15 \%$ for seed yield (SY/P). Days to $50 \%$ flowering showed negative correlations with all traits except height to first capsule (HFC). Height to first capsule was negatively correlated with length of fruiting zone (LFZ), 1000-SW, oil\% and infection\%, and positively correlated with capsules/plant (NC/P) and SY/P. Single trait selection was an efficient method to improve selection criterion, but it caused adverse effects on some correlated traits. Selection for days to $50 \%$ flowering improved earliness, but it was better in improving yield if the selection was restricted by SY/P. Selection for oil\% restricted by yield was better in improving yield than selection for oil\% per se. Therefore, the inclusion of a trait as independent culling level improved the efficiency of selection. The best genetic gain in SY/P in percentage from the mid-parent was obtained from selection for days to $50 \%$ flowering restricted by SY/P $\left(35.56^{* *}\right)$, LFZ restricted by HFC $\left(19.53^{* *}\right)$, days to 50\% flowering $\left(19.32^{* *}\right)$, oil\% restricted by SY/P $\left(19.02^{* *}\right)$, SY/P $\left(17.38^{* *}\right), 1000 \mathrm{SW}\left(14.09^{* * *}\right)$ and LFZ $\left(14.032^{* *}\right)$. Therefore, selection index incorporating favorable trait is recommended.
\end{abstract}

Keywords: Sesame; Fusarium oxysporum; Pedigree selection; Genotypic correlation; Observed gain.

\section{Introduction}

Sesame (Sesamum indicum L., belongs to family Pedaliaceae) is one of the most ancient oilseed crops known to mankind (Nayar, 1984; Bedigian and Harlan, 1986). Its cultivation goes back to 2130 B.C.(Weiss, 1983). It is cultivated in the tropical and subtropical regions of the world (Ashri,1994) as a source of excellent vegetable oil, and has one of the highest oil contents (3563\%) among oil crops (Ashri, 2010; and Baydar et al., 1999). The oil is very stable due to the presence of a number of antioxidants such as

*Corresponding author: Ezzat E. Mahdy, Email: ezzat.mahdy@agr.au.edu.eg

Received: September 20, 2021; Accepted: October 5, 2021;

Published online: October 15, 2021

(C) Published by South Valley University.

This is an open access article licensed under $@(\$)$ sesamin, sesamolin and sesamol (Suja et al., 2004). Therefore, it has a long shelf life and can be blended with less stable vegetable oils to improve their stability and longevity (Chung et al., 2006). The cultivated area in the world was $11,743,382$ ha in 2018. The production was 6015573t (FAO. 2019). Wherever sesame is grown, it is infected by various pathogens. Macrophomina phaseolina (Tassi) Goid and Fusarium oxysporum f. sp sesami are serious pathogens that cause root rot and wilt diseases and decrease yield. Many authors worked on evaluation and selection in sesame. Bharathi et al. (2014), (Iqbal, 2016) and Saravanan et al. (2020) indicated that the magnitude of GCV and PCV was high for seed yield per plant, number of capsules per plant and number of branches 
per plant. Mahdy et al. (2015a) and Ismail et al. (2014) found slight discrepancy between GCV and PCV. Patil and Lokesha (2018) and Shammoro et al. (2020) came to the same conclusion.

High heritability and genetic advance in percentage of the mean was recorded for seed yield per plant and number of capsules per plant, indicating that selection could be effective for improving these characters (Abatchoua et al., 2014; Ismail et al., 2014; Fazal et al., 2015; Mahdy et al., 2015b). 1000 seed weight exhibited a high heritability along with a high genetic advance in percent of the mean (Vanishree et al., 2011; Kanak and Rajani, 2016 and Singh et al., 2018). Mohanty et al. (2020) estimated expected genetic from the mean for oil\% of $31.50 \%$. Jyothi et al. (2011) screened 35 sesame germplasm accessions. All the accessions displayed some percent infection rate, and none could be described as immune.

Capsules/Plant showed positive significant $(\mathrm{p} \leq 0.01)$ correlation with SY/P (Mahdy et al 2015b, Sopundharya et al. 2017 and Disowja et al., 2020) and days to maturity showed negative correlation with yield/plant. Patidar et al. (2020) reported that the direct effect of number of seeds/capsule (0.661) on seed yield $(\mathrm{kg} / \mathrm{ha})$ was positive and highly significant followed by number of capsules/plant (0.524), oil content (0.181) and 1000 seed weight (0.117).

This study aimed to improve tolerance and/or resistance of sesame to $F$. oxysporum through two cycles of pedigree selection under artificial infection in the field using one population in the $\mathrm{F}_{3^{-}}$generation, gather information's on variability, correlation, heritability, and genetic gain from selection.

\section{Materials and methods}

The present work was carried out at Fac. Agric. Farm, Assiut University during the three summer seasons of 2016-2018. The experimental site was artificially infected each year by the pathogen Fusarium oxysporum f. sp. sesami.

\subsection{Genetic Materials}

The materials used was one population of sesame (Sesamum indicum L.) in the $\mathrm{F}_{3}$ generation provided by Agriculture Research Center. This population was subjected in the $\mathrm{F}_{2-}$ generation to artificial infection in the field and selection was for resistance to $F$. oxysporum. The population stemmed from the cross Shandaweel 3/ Introduction 688. The growing seasons, planting dates, and experimental design were as follows

\begin{tabular}{cccc}
\hline Season & Date & $\begin{array}{c}\text { Gener } \\
\text { ation }\end{array}$ & Experimental design \\
\hline 2016 & $21 / 4 /$ & $\mathrm{F}_{3}$ & RCBD with three replications \\
& 2016 & & \\
2017 & $3 / 7 /$ & $\mathrm{F}_{4}$ & RCBD with three replications \\
& 2017 & & \\
2018 & $3 / 7 /$ & $\mathrm{F}_{5}$ & RCBD with three replications \\
& 2018 & & \\
\hline
\end{tabular}

\subsection{Season 2016; F3- generation}

2.2.1. Isolation and preparation of Fusarium oxysporum f. sp. sesame.

Fungus was grown on a media of Potato Dextrose Agar (PDA) which consisted of (200g potatoes, $20 \mathrm{~g}$ dextrose, $20 \mathrm{~g}$ agar and $1000 \mathrm{ml}$ distilled water). The media was autoclaved at $120^{\circ} \mathrm{C}$ for 20 minutes. The media was poured in Petri dishes $(9 \mathrm{~cm}$ diameter $\times 1.5 \mathrm{~cm})$ under sterilized conditions and was inoculated by the fungus under these sterilized conditions and then incubated at $25-30^{\circ} \mathrm{C}$ in the dark for 15 days. Inoculum of the tested isolate was prepared by growing in sterilized glass bottles (500-ml) containing barley medium (150 g barley seeds, $4 \mathrm{~g}$ glucose, and $200 \mathrm{ml}$ water) and autoclaved in two consecutive days. A7 mm disk was cut from the margin of 5-day-old actively growing culture of the isolate and placed at the barley medium and incubated at $28 \pm 2^{\circ}$ for two weeks. Inoculum for the isolate was prepared by inoculating sterilized $1000 \mathrm{ml}$ conical flasks containing barley medium (150 g barley+ $4 \mathrm{~g}$ 
glucose $+200 \mathrm{ml}$ water) with the tested fungal isolate followed by incubation at $28 \pm 2^{\circ}$ for two weeks. Soil infestation was carried out by adding the inoculum of isolate to soil at the rate $2 \%$ barley medium contains fungus. Identification of the isolated fungus was carried out on 5-12 days old culture using the morphological and microscopic characteristics of mycelium and spores according to (Booth, 1971) and (Mahmoud, 2016)

\subsubsection{Sowing and data collection}

Seeds were sown in rows, $4.0 \mathrm{~m}$ long and $10 \mathrm{~cm}$ between hills. The parents were sown each in five rows. The experimental unit was one row except for the parents. After full emergence, seedlings were thinned to one plant per hill. The recommended cultural practices for sesame production were adopted throughout the three growing seasons. The number of families was 200 along with the parents. At harvest, data were recorded on ten random survival plants for each family in each replication for days to $50 \%$ flowering, plant height $(\mathrm{PH}, \mathrm{cm})$, height to the first capsule $\mathrm{cm}(\mathrm{HFC}, \mathrm{cm})$, length of the fruiting zone (LFZ, cm), capsule length (CL, $\mathrm{cm})$, capsule width $(\mathrm{CW}, \mathrm{cm})$, number of capsules/plant (NC/P), seed yield/ plant (SY/P, g), 1000-seed weight (SW, g), seed oil\% and infection\% (Inf\%) (the wilted plants were recorded at seedling stage and at harvest). The total survival families were 188. The selection criteria were days to $50 \%$ flowering, days to $50 \%$ flowering restricted by SY/P (the earliest families that gave SY/P that was not less than the average of the families), LFZ, LFZ restricted by HFC, 1000-seed weight, SY/P, seed oil\%, seed oil\% restricted by SY/P. At harvest, the best survival plant from each of the top 10 families based on yield was saved for the next season.

\subsection{Second season, F4- generation}

The ten selected plants tolerant to $F$. oxysporum for each selection criterion were evaluated along with the parents in the field under artificial infection as in the previous season. At the end of the season, seeds of the top 5 plants for each selection criterion were saved.

\subsection{Third season, $F_{5^{-}}$generation}

The selected families tolerant to $F$. oxysporum along with the parents and were evaluated in the field under artificial infection as in the previous season.

\subsection{Statistical analysis}

The analysis of variance, phenotypic variance $\left(\sigma_{p}^{2}\right)$ and genotypic variance $\left(\sigma_{g}^{2}\right)$ were performed as ( Steel et al., 1997). The analysis of variance of infection percentage was done on Arcsine transformed data. Heritability in broad sense $(\mathrm{H} \%)=\left(\sigma_{\mathrm{g}}^{2} / \sigma_{\mathrm{p}}^{2}\right) \times 100$, and expected genetic gain $=\mathrm{k} \sigma_{\mathrm{p}} \mathrm{h}^{2}$ based on $10 \%$ selection intensity was estimated as Falconer (1989), heritability in narrow sense $\left(\mathrm{h}^{2}\right)$ was calculated as (Smith and Kinman, 1965). The phenotypic and genotypic coefficients of variation were estimated using the formula developed by (Burton, 1952). Deviation of the observed direct and correlated genetic advance to selection in percentage from the better and the mid-parent was measured using LSD test. Genotypic and phenotypic correlations were estimated according to (Miller et al., 1958)

\section{Results and discussion}

\subsection{Description of the base populations; season of 2016 ( $F_{3^{-}}$generation)}

\subsubsection{Means and variances}

The analysis of variance (Table1) of the morphological traits, yield, and yield components was done on the survival families $\left(\mathrm{F}_{3^{-}}\right.$generation). Families mean squares were significant $(p \leq 0.01)$ for all the studied traits in the population except capsule length and capsule width. Therefore, capsule length and width were omitted from all analyses. The phenotypic (PCV) coefficient of variability (Table1) indicated that the lowest variability was recorded for days to $50 \%$ flowering $(5.37 \%)$. 
However, moderate to high GCV was obtained variability varied from $4.34 \%$ for days to $50 \%$ flowering to $38.15 \% \mathrm{SY} / \mathrm{P}$. These results are in line with many authors. Bharathi et al (2014) indicated that the magnitude of GCV and PCV, respectively, was high for seed yield per plant (47.18 and $50.26 \%$ ), number of capsules per for the other traits. Genotypic coefficient of plant (37.12 and $41.02 \%)$ and number of branches per plant (33.84 and 38.56\%). (Mahdy et al. 2015a) found slight discrepancy between GCV and PCV. Iqbal (2016a), Patil and Lokesha, (2018) and Shammoro 2020 et al.(2020) came to the same conclusion.

Table 1. Mean squares, heritability in broad sense (H), genotypic (GCV \%) and phenotypic (PCV \%) coefficients of variability of the families in the F3-generation season 2016, F3- mean, parental means, maximum and minimum values under artificial infection by $F$. oxysporum

\begin{tabular}{|c|c|c|c|c|c|c|c|c|c|c|c|}
\hline S.V. & d.f & $\begin{array}{c}50 \% \text { flo } \\
\text { w }\end{array}$ & $\mathrm{PH}, \mathrm{cm}$ & $\begin{array}{c}\mathrm{HFC}, \\
\mathrm{cm}\end{array}$ & LFZ, cm & $\mathrm{NC} / \mathrm{P}$ & $\mathrm{SY} / \mathrm{P}, \mathrm{g}$ & $\begin{array}{c}1000 \mathrm{~S} \\
\mathrm{~W}\end{array}$ & OIL \% & $\begin{array}{c}\text { INF\% } \\
\text { Seedling }\end{array}$ & $\begin{array}{c}\text { INF\% } \\
\text { at } \\
\text { harves } \\
t\end{array}$ \\
\hline Reps & 2 & 0.25 & 974.01 & 40.69 & 1406.00 & 1188.00 & 373.25 & 0.10 & 3.00 & 0.81 & 32.88 \\
\hline Entries & 189 & $33.39 * *$ & $\begin{array}{c}1375.54 \\
* *\end{array}$ & $\begin{array}{c}324.39 * \\
*\end{array}$ & $\begin{array}{c}1512.90 \\
* *\end{array}$ & $\begin{array}{c}62862.78 * \\
*\end{array}$ & $\begin{array}{c}1314.25^{*} \\
*\end{array}$ & $\begin{array}{c}0.64 * \\
*\end{array}$ & $\begin{array}{c}98.37 * \\
*\end{array}$ & $\begin{array}{c}172.13 * \\
*\end{array}$ & $\begin{array}{c}173.05 \\
* *\end{array}$ \\
\hline Error & 378 & 0.349 & 127.83 & 91.32 & 142.68 & 7826.69 & 59.48 & 0.05 & 0.87 & 6.32 & 6.07 \\
\hline PCV\% & & 5.37 & 12.70 & 22.80 & 18.26 & 36.09 & 39.05 & 9.09 & 10.93 & 16.41 & 10.67 \\
\hline GCV\% & & 5.34 & 12.10 & 19.33 & 17.38 & 33.77 & 38.15 & 8.75 & 10.88 & 16.11 & 10.48 \\
\hline $\mathrm{H} \%$ & & 98.95 & 90.71 & 71.85 & 90.57 & 87.55 & 95.47 & 92.56 & 99.12 & 96.33 & 96.50 \\
\hline $\mathrm{F}_{3}$ - mean & & 62.11 & 168.56 & 45.60 & 122.95 & 401.07 & 53.60 & 5.10 & 52.40 & 46.15 & 71.17 \\
\hline $\operatorname{Max}$ & & 76.67 & 208.33 & 83.33 & 178.33 & 1174.00 & 114.04 & 6.59 & 66.00 & 57.50 & 82.50 \\
\hline Min & & 54.33 & 105.00 & 26.67 & 55.00 & 121.17 & 6.12 & 4.18 & 25.00 & 25.00 & 50.00 \\
\hline GA & & 5.81 & 34.18 & 13.15 & 35.79 & 223.04 & 35.17 & 0.76 & 9.99 & 12.84 & 12.90 \\
\hline GA/mean*100 & & 9.35 & 20.28 & 28.83 & 29.11 & 55.61 & 65.61 & 14.81 & 19.07 & 27.82 & 18.12 \\
\hline Mean Shandaweel & & 59.67 & 138.33 & 45.00 & 93.33 & 227.33 & 29.81 & 5.46 & 59.33 & 52.50 & 77.50 \\
\hline Mean Int688 & & 69.33 & 151.67 & 41.67 & 110.00 & 378.00 & 39.60 & 5.34 & 54.00 & 45.00 & 72.50 \\
\hline
\end{tabular}

*, **, significant at 0.05 and 0.01 levels of probability; respectively. $\mathrm{GA}=$ expected genetic advance from selection $10 \%$ superior families.

Heritability estimates in broad sense in the $\mathrm{F}_{3^{-}}$ generation were high and ranged from $71.85 \%$ for $\mathrm{PH}$ to $96.50 \%$ for infection\%. These estimates of heritability are considered biased upward because the evaluation in one location for one season inflated families mean squares by the confounding effects of the interaction of families with locations and years. The expected genetic advance from selection of $10 \%$ superior families in percentage of the $\mathrm{F}_{3^{-}}$generation mean ranged from $9.35 \%$ for $50 \%$ flowering to $65.61 \%$ for SY/P, it depended mainly on phenotypic variance rather than heritability. These results are in line with those reported by
Abatchoua et al. (2014), Fazal et al. (2015), Ismail et al. (2014), Mahdy et al. (2015b) and Vanishree et al. (2011). Kanak and Rajani (2016) recorded high heritability and genetic advance in percentage of the mean for seed yield per plant (97.5 and 6.83\%, respectively) followed by number of capsules per plant (96.6 and $1.72 \%$, respectively) indicating that selection could be effective for improving these characters

The $\mathrm{F}_{3}$ - mean and parental means are shown in Table 1. The number of survival families that could be considered tolerant to $F$. oxysporum was 188 out of 215 families. Furthermore, the 
two parents Shandaweel 3 and Introduction 688 were severely damaged by $F$. oxysporum. The maximum and minimum values in the $F_{3^{-}}$ generation survival families indicated the feasibility of selection for $50 \%$ flowering, $\mathrm{PH}$, HFC. LFZ, NC/P, SY/P, 1000-SW and oil\%. Family means ranged in days to $50 \%$ flowering from 54.33 to 76.67 , plant height from 105.00 to $208.33 \mathrm{~cm}$, height to the first capsule from 26.67 to $83.33 \mathrm{~cm}$, length of the fruiting zone from 55.00 to $178.33 \mathrm{~cm}$., 1000 -seed weight from 4.18 to $6.59 \mathrm{~g}$, capsules/plant from 121.17 to 1174.00 , seed yield/plant from 6.12 to $114.04 \mathrm{~g}$, seed oil percentage from 25.00 to $66.00 \%$. Such wide range of variability was sufficient for selection.

\subsubsection{Genotypic and phenotypic correlations in the base populations ( $F_{3}$ generation)}

Days to $50 \%$ flowering showed negative correlations with all traits except HFC at genotypic and phenotypic levels (Table 2), indicating that the early families had the favorable traits. Likewise, $\mathrm{PH}$ gave positive correlations with all traits except INF\%, meaning that the tall plants were favorable in all traits. The highest correlation of $\mathrm{PH}$ was with LFZ $\left(0.9120 r_{g}, 0.8887 r_{p}\right)$. Tall plants gave large $\mathrm{NC} / \mathrm{P}$, long FZ, high yielding ability and low infection \%. Height to first capsule negatively correlated with LFZ, $1000 \mathrm{SW}$, oil\% and INF\%, and positively correlated with $\mathrm{NC} / \mathrm{P}$ and SY/P, meaning that the high yielding plants with high NC/P had high first capsule. These findings recommended the use of multiple trait selection. Length of fruiting zone showed positive correlations at genotypic and phenotypic levels with NC/P, SY/P, 1000 SW and oil\% and negative with INF\%. Seed yield/plant gave high correlations with NC/P $\left(r_{g}=0.6324, r_{p}=0.6087\right)$. These findings are in line with those of many authors. Mahdy et al. (2015b) showed positive significant $(\mathrm{p} \leq 0.01)$ correlation of $\mathrm{NC} / \mathrm{P}$ with seed yield/plant in two populations $(0.183$ and 0.538). Otherwise, days to first flower showed negative significant correlation with number of capsules/plants. (Soundharya et al., 2017) found

Table 2. Genotypic (above) and phenotypic correlation coefficients (below diagonal) among the traits in the $\mathrm{F}_{3}$-generation in population under artificial infection of Fusarium oxysporum.

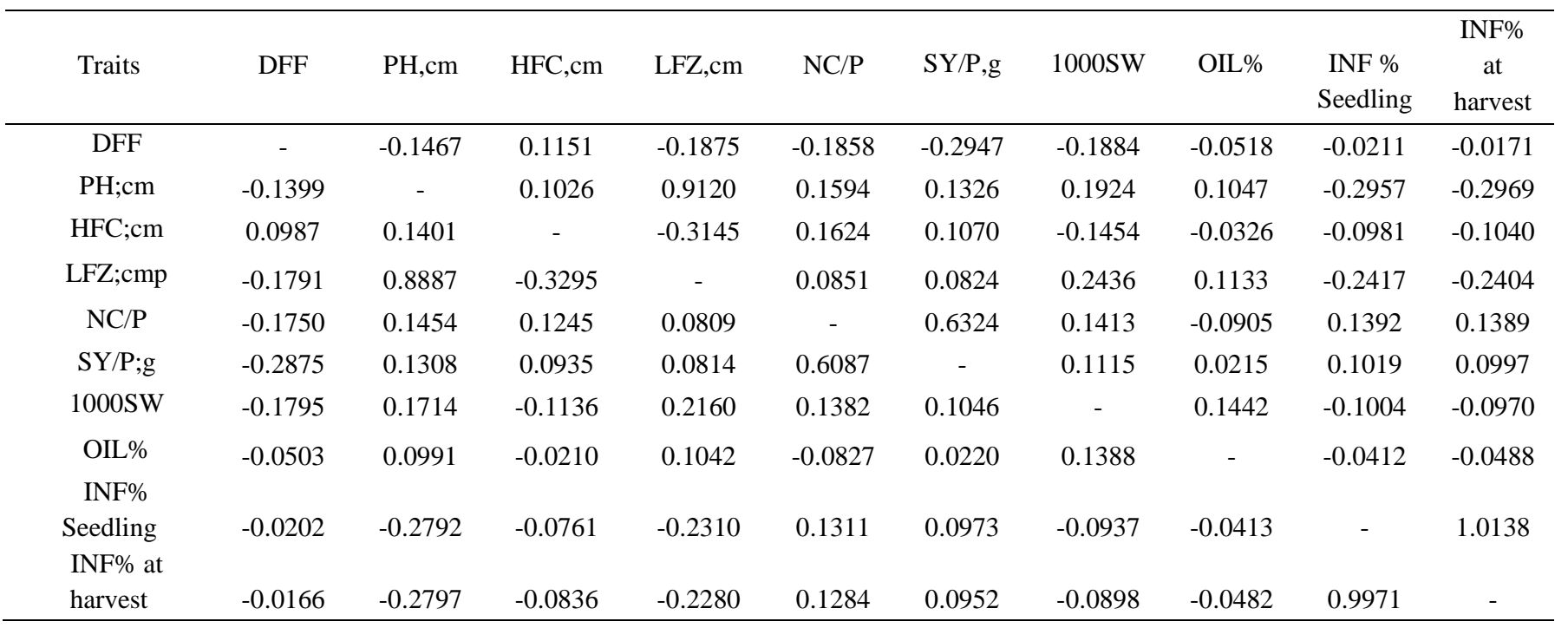

that Number of capsules/plants showed positive significant $(\mathrm{p} \leq 0.01) \quad$ correlation with seed yield/plant in two populations (0.183 and 0.538$)$.
( Disowja et al., 2020) indicated that the capsules/plant recorded a high positive and significant genetic correlation with yield/plant. 
Maturity days showed negative correlation with yield / plant (0.162 rg, $0.120 \mathrm{rp}$ ). Patidar et al. (2020) reported that the direct effect of number of seeds/capsule (0.661) on seed yield ( $\mathrm{kg} / \mathrm{ha})$ was positive and highly significant followed by number of capsules/plant (0.524), Oil content (0.181) and 1000 seed weight (0.117).

3.2. Evaluation of the second cycle selection, season 2018

\section{Variability and heritability estimates}

Mean squares of the entries (families + parents) of all the selection criteria were significant $(\mathrm{p} \leq$ 0.01) after two cycles selection (Table 3) indicating the presence of variability in the selection criterion for further cycles of selection. The remained variability after selection expressed as GCV\% and PCV\% could be considered low (Table 4) for flowering and oil\%, moderate for LFZ restricted by HFC and
1000 SW, and high for SY/P and LFZ. The significant differences of the entries, which in the analysis of variance of the low GCA and PCV caused by the inclusion of the two parents in the analysis.

Heritability in broad sense of the selection criteria were very high and unreliable (Table 4) because the evaluation for one season and one location inflated families mean squares by the confounding effects of the interaction of families, years and locations. Otherwise, heritability in narrow sense as estimated by regression was considered high in the $\mathrm{F}_{5}$ for flowering, SY/P and Oil\% and very low for the other traits in both of $\mathrm{F}_{4}$ and $\mathrm{F}_{5}$-generations. This is due to the fact that the pathogen kills susceptible families regardless of their performance in any trait.

Table 3. Mean squares of the selected families for the eight selection criteria in the $\mathrm{F}_{5}$-generation, season 2018.

\begin{tabular}{lccccccccc}
\hline S.V. & d.f & 50\% flow & $\begin{array}{c}\text { Flow.Res. } \\
\text { by yield }\end{array}$ & SY/P & Oil\% & $\begin{array}{c}\text { Oil\% Res. by } \\
\text { yield }\end{array}$ & LFZ & $\begin{array}{c}\text { LFZ. Res. by } \\
\text { HFC }\end{array}$ & $\begin{array}{c}1000 s w \\
\text { Reps }\end{array}$ \\
\hline Entries & 6 & 3.7619 & 3.76 & 0.810 & 4.3333 & 4.332 & 72.62 & 72.62 & 0.10 \\
Error & 12 & 0.4286 & 0.43 & 8.346 & 0.2220 & 0.111 & 53.17 & 74.01 & 0.004 \\
\hline
\end{tabular}

Res. =restricted, **, significant at 0.01 levels of probability

Table 4. Genotypic (GCV \%), phenotypic coefficients of variability (PCV\%), heritability in broad $(\mathrm{H} \%)$ and in narrow sense $\left(\mathrm{h}^{2}\right)$ for the selection criteria in the $\mathrm{F}_{5^{-}}$generation. $7 / 15$

\begin{tabular}{lccccc}
\hline Selection criterion & $\mathrm{GCV} \%$ & $\mathrm{PCV} \%$ & $\mathrm{H} \%$ & $\mathrm{~h}^{2}\left(\mathrm{~F}_{4} / \mathrm{F}_{3}\right)$ & $\mathrm{h}^{2}\left(\mathrm{~F}_{5} / \mathrm{F}_{4}\right)$ \\
\hline 50\% Flowering & 4.14 & 4.21 & 96.81 & 0.90 & 0.23 \\
50\% Flow. restricted by yield & 5.20 & 5.25 & 98.03 & 0.90 & 0.75 \\
Seed yield/plant & 16.47 & 17.38 & 89.85 & 0.81 & 0.18 \\
Oil\% & 6.41 & 6.43 & 99.54 & 0.75 & 0.93 \\
Oil\% restricted by yield & 5.80 & 5.81 & 99.71 & 0.61 & 0.39 \\
LFZ & 14.94 & 15.58 & 92.02 & 0.05 & 0.86 \\
LFZ restricted by HFC & 9.69 & 10.92 & 78.76 & 0.15 & 0.23 \\
1000-SW & 7.92 & 7.95 & 99.19 & 0.19 & 0.10
\end{tabular}

Many authors are in line with these findings. (Ismail et al., 2014) noted that the slight discrepancy between (GCV) and (PCV) resulted in high estimates of broad sense heritability for most studied traits in the two base populations. (Aladji et al., 2014), 
(Bharathi et al., 2014) and (Mahdy et al., 2015a,b). (Iqbal et al., 2016) and (Saravanan et al., 2020) noted high GCV and PCV\% of (26.11 and 26.30) for yield per plant. (Fazal et al., 2015) found that heritability in the broad sense was high for days to flowering (89.20\%). (Kanak and Rajani, 2016) found high heritability and genetic advance in percentage of the mean seed yield per plant (97.5 and 6.83\%, respectively) followed by number of capsules per plant (96.6 and $1.72 \%$, respectively) indicating that selection could be effective for improvement of these characters.

\subsubsection{Means and direct observed genetic gain in days to $50 \%$ flowering}

After the second cycle $\left(\mathrm{F}_{5}\right)$ selection for days to $50 \%$ flowering, the five selected families become alike to large extent. They ranged from 50.00 to 51.00 day indicating the great depletion of variability, and the significantly in families mean square caused by the inclusion of the parents in the analysis of variance.

The direct genetic response in days to $50 \%$ flowering (Table 5) was significant from the mid-parent $\left(-7.77 \%^{* *}\right)$ and from the betterparent $\left(-6.91 \%^{* * *}\right)$ followed by positive significant correlated gain from the mid-parent in $\mathrm{PH}\left(16.99 \%^{* *}\right), \operatorname{HFC}\left(51.83 \%^{* *}\right), \mathrm{SY} / \mathrm{P}$ $\left(19.32 \%^{* *}\right)$, and $1000 \mathrm{SW}\left(7.47 \%^{*}\right)$. Otherwise, significant negative correlated gains were recorded for oil\% $\left(-6.08 \%{ }^{* *}\right)$ and infection\% at harvest $\left(-1.7 \%^{* *}\right)$. These results are in line with those of Mahdy et al. (2015b).

Table 5. Selected family means of days to $50 \%$ flowering and correlated traits in the $\mathrm{F}_{5}$-generation, observed gain from the midparent (GA-MP \%) and better parent (GA-BP \%) under artificial infection of Fusarium oxysporum.

\begin{tabular}{|c|c|c|c|c|c|c|c|c|c|c|}
\hline Fam. No. & $\begin{array}{l}\$ 0.50 \\
\text { Flow }\end{array}$ & $\mathrm{PH}, \mathrm{cm}$ & $\mathrm{HFC}, \mathrm{cm}$ & LFZ, cm & $\mathrm{NC} / \mathrm{P}$ & $\mathrm{SY} / \mathrm{P}, \mathrm{g}$ & 1000SW & OIL\% & $\begin{array}{c}\text { INF \% } \\
\text { Seedling }\end{array}$ & $\begin{array}{c}\text { INF\% } \\
\text { at harvest }\end{array}$ \\
\hline 19 & 51.00 & 171.67 & 75.00 & 96.67 & 104.33 & 19.48 & 5.49 & 54.00 & 41.90 & 44.29 \\
\hline 138 & 50.33 & 141.67 & 55.00 & 86.67 & 83.03 & 26.64 & 5.30 & 52.00 & 58.93 & 61.71 \\
\hline 152 & 50.00 & 163.33 & 61.67 & 101.67 & 144.33 & 19.48 & 5.35 & 52.00 & 61.41 & 62.57 \\
\hline 195 & 50.00 & 133.33 & 51.67 & 81.67 & 133.52 & 32.53 & 5.40 & 49.00 & 53.53 & 54.51 \\
\hline 210 & 50.00 & 101.67 & 35.00 & 66.67 & 82.43 & 21.18 & 5.63 & 60.67 & 55.00 & 55.26 \\
\hline Average & 50.27 & 142.33 & 55.67 & 86.67 & 109.53 & 23.86 & 5.44 & 53.53 & 54.15 & 55.67 \\
\hline M-P & 54.50 & 121.67 & 36.67 & 85.00 & 108.78 & 20.00 & 5.06 & 57.00 & 54.41 & 56.68 \\
\hline GA-MP\% & $-7.77 * *$ & $16.99 * *$ & $51.82 * *$ & 1.96 & 0.69 & $19.32 * *$ & $7.47 * *$ & $-6.08 * *$ & $-0.47 * *$ & $-1.78 * *$ \\
\hline GA-BP\% & $-6.91 * *$ & 6.75 & $85.56 * *$ & -3.70 & -32.53 & 4.46 & $-5.84 * *$ & $-12.24 * *$ & $10.34 * *$ & $9.61 * *$ \\
\hline Shandaweel 3 & 55.00 & 133.33 & 43.33 & 90.00 & 162.33 & 17.15 & 5.77 & 53.00 & 49.08 & 50.79 \\
\hline Introduction 688 & 54.00 & 110.00 & 30.00 & 80.00 & 55.22 & 22.84 & 4.34 & 61.00 & 59.74 & 62.57 \\
\hline MP LSD0.05\% & 1.01 & 10.16 & 6.79 & 11.42 & 25.81 & 4.99 & 0.11 & 0.73 & 0.05 & 0.12 \\
\hline MP LSD $0.01 \%$ & 1.41 & 14.24 & 9.53 & 16.02 & 36.18 & 7.00 & 0.15 & 1.02 & 0.07 & 0.17 \\
\hline BP LSD $0.05 \%$ & 1.17 & 11.73 & 7.85 & 13.19 & 29.80 & 5.77 & 0.13 & 0.84 & 0.06 & 0.14 \\
\hline BP LSD $0.01 \%$ & 1.63 & 16.44 & 11.00 & 18.49 & 41.78 & 8.09 & 0.18 & 1.18 & 0.08 & 0.19 \\
\hline
\end{tabular}

$\S=$ selection criterion, ${ }^{*}, * *$, significant at 0.05 and 0.01 levels of probability; respectively.

3.2.2. Means and direct observed genetic gain in days to 50\% flowering restricted by SY/P
After the second cycle $\left(\mathrm{F}_{5}\right)$ selection for days to $50 \%$ flowering restricted by $\mathrm{SY} / \mathrm{P}$, the five 
selected families become similar except one. They ranged from 50.00 to 56.00 day indicating the great depletion of variability. The direct genetic response in days to $50 \%$ flowering (Table 6) was significant from the mid-parent ($5.93 \% * *)$ and from the better- parent ($5.06 \% * *)$ followed by positive significant correlated gain from the mid-parent in $\mathrm{PH}$ $(14.26 \% * *), \quad \mathrm{HFC} \quad(44.55 \% * *), \quad \mathrm{SY} / \mathrm{P}$ $(35.56 \% * *)$, and $1000 \mathrm{SW}(4.54 \% *)$. Otherwise, significant negative correlated gains were recorded for oil \% (-4.68\%**) and infection\% at harvest $(-1.68 \% * *)$. These results are in line with those of Mahdy et al. (2015b).

Table 6. Selected family means of days to $50 \%$ flowering restricted by seed yield and correlated traits in the $\mathrm{F}_{5}$-generation, observed gain from the mid-parent (GA-MP\%) and better parent (GA-BP\%).

\begin{tabular}{|c|c|c|c|c|c|c|c|c|c|c|}
\hline \multirow[t]{2}{*}{ Fam. No. } & \multicolumn{2}{|c|}{ Selectom criteria } & \multicolumn{8}{|c|}{ Correlated traits } \\
\hline & 0.50 & $\mathrm{SY} / \mathrm{P}, \mathrm{g}$ & $\mathrm{PH}, \mathrm{cm}$ & $\mathrm{HFC}, \mathrm{cm}$ & LFZ, $\mathrm{cm}$ & $\mathrm{NC} / \mathrm{P}$ & 1000 & OIL \% & INF \% & INF\% \\
\hline 138 & 50.33 & 26.64 & 141.67 & 55.00 & 86.67 & 83.03 & 5.30 & 52.00 & 58.93 & 61.71 \\
\hline 152 & 50.00 & 19.48 & 163.33 & 61.67 & 101.67 & 144.33 & 5.35 & 52.00 & 61.41 & 62.57 \\
\hline 195 & 50.00 & 32.53 & 133.33 & 51.67 & 81.67 & 133.52 & 5.40 & 49.00 & 53.53 & 54.51 \\
\hline 199 & 56.00 & 84.85 & 155.00 & 61.67 & 93.33 & 294.00 & 4.75 & 58.00 & 46.79 & 54.10 \\
\hline 210 & 50.00 & 21.18 & 101.67 & 35.00 & 66.67 & 82.43 & 5.63 & 60.67 & 55.00 & 55.26 \\
\hline Average & 51.27 & 36.93 & 139.00 & 53.00 & 86.00 & 147.46 & 5.29 & 54.33 & 55.13 & 57.63 \\
\hline M-P & 54.50 & 20.00 & 121.67 & 36.67 & 85.00 & 108.78 & 5.06 & 57.00 & 54.41 & 56.68 \\
\hline GA-MP $\%$ & $-5.93 * *$ & $84.69^{* *}$ & $14.25^{* *}$ & $44.55^{* *}$ & 1.18 & $35.56 * *$ & $4.54 * *$ & $-4.68 * *$ & $1.33 * *$ & $1.68 * *$ \\
\hline GA-BP $\%$ & $-5.06 * *$ & $61.69^{* *}$ & 4.25 & $76.67 * *$ & -4.44 & -9.16 & $-8.41^{* *}$ & $-10.93 * *$ & $12.33 * *$ & $13.47 * *$ \\
\hline Shandaweel 3 & 55.00 & 17.15 & 133.33 & 43.33 & 90.00 & 162.33 & 5.77 & 53.00 & 49.08 & 50.79 \\
\hline Introduction & 54.00 & 22.84 & 110.00 & 30.00 & 80.00 & 55.22 & 4.34 & 61.00 & 59.74 & 62.57 \\
\hline MP LSD0.05\% & 1.01 & 7.26 & 9.61 & 6.06 & 11.69 & 18.70 & 0.13 & 0.89 & 0.28 & 0.37 \\
\hline MP LSD0.01\% & 1.41 & 10.18 & 13.47 & 8.50 & 16.39 & 26.22 & 0.19 & 1.25 & 0.39 & 0.52 \\
\hline BP LSD0.05\% & 1.16 & 8.39 & 11.09 & 7.00 & 13.50 & 21.59 & 0.15 & 1.03 & 0.32 & 0.42 \\
\hline BP LSD0.01\% & 1.63 & 11.76 & 15.56 & 9.81 & 18.92 & 30.27 & 0.21 & 1.44 & 0.45 & 0.60 \\
\hline
\end{tabular}

*, **, significant at 0.05 and 0.01 levels of probability; respectively.

\subsubsection{Means and direct observed genetic gain in seed yield/plant}

After two cycles of selection for SY/P, wide range of variation in SY/P was found (Table 7). Family means ranged from 21.18 to 34.34 $\mathrm{g} / \mathrm{plant}$ with an average of $30.13 \mathrm{~g}$. A wide range of variation was observed in the other correlated traits. Infection \% at harvest, the family means ranged from 50.70 to $62.5 \%$ with an average of $55.20 \%$. The direct significant $(\mathrm{p} \leq 0.01)$ observed genetic gain in SY/P was $17.38 \%$ from the mid-parent, while it was not significant from the better parent. The increase in yield followed by significant decrease in days to $50 \%$ flowering $(-2.02$ and $-1.11 \%)$, in LFZ (-14.12 and $18.89 \%)$, oil\% (-7.84 and $-13.88 \%)$ and infection $\%$ at harvest (-2.2 and 9.0\%) from the mid and better parent, respectively. It could be noticed that the pedigree selection for SY/P accompanied with favorable decrease in days to $50 \%$ flowering, and infection $\%$ at harvest, and adversely affected LFZ and Oil\%. It is the main drawback of single trait selection, it is efficient in changing the mean of the selection criterion, 
and adversely affects some correlated characters. These results are in line with those found by (Ismail et al., 2014) and (Mahdy et al., 2015a). In a study of 15 populations in the $\mathrm{F}_{3}$ and $\mathrm{F}_{4} \mathrm{EL}$ Bramawy (2006) indicated that selection for both Fusarium wilt resistance and seed yield could be feasible and lead to resistant cultivars with seed yield potential. El-Bramawy and Abd Al-Wahid (2007) noticed that the high resistance entries gave the lowest seed yield. so, great care should be taken during selection for breeding program. (Jyothi et al., 2011) screened 35 sesame germplasm accessions. All the accessions displayed some percent infection rate, and none could be described as immune. (Ngamba et al., 2020) stated that the genotypes

differed significantly $(\mathrm{P} \leq 0.001)$ for disease incidence.

\subsubsection{Means and direct observed genetic gain in seed oil\%}

Mean oil\% after two cycles of selection ranged from 60.33 to $65.0 \%$ with an average of $62.73 \%$ compared to 53.00 and $61.00 \%$ of the two parents (Table 8). The genetic direct observed gain in oil $\%$ was significant $(\mathrm{p} \leq 0.01)$ from the mid-parent $(10.06 \%)$ and from the better parent $(2.84 \%)$. Selection for oil\% accompanied with significant delay in flowering, increase in HFC, 1000-SW, and INF\% was observed. Otherwise, selection for oil\% showed insignificant decrease of the observed correlated gain from the mid parent in LFZ, NC/P and SY/P.

Table 7. Selected family means for seed yield/ plant and correlated traits in the $\mathrm{F}_{5}$-generation, observed gain from the mid-parent (GA-MP\%) and better parent (GA-BP\%) under artificial infection by Fusarium oxysporum.

\begin{tabular}{|c|c|c|c|c|c|c|c|c|c|c|}
\hline \multirow[b]{2}{*}{ Fam. No. } & \multicolumn{5}{|l|}{ Sel.cri } & \multicolumn{5}{|c|}{ Correlated traits } \\
\hline & $\mathrm{SY} / \mathrm{P}, \mathrm{g}$ & $\begin{array}{l}50 \% \\
\text { flow }\end{array}$ & $\mathrm{PH}, \mathrm{cm}$ & $\mathrm{HFC}, \mathrm{cm}$ & LFZ, cm & $\mathrm{NC} / \mathrm{P}$ & $\begin{array}{l}1000 \\
\text { SW }\end{array}$ & OIL\% & INF \% Seedling & $\begin{array}{l}\text { INF\% } \\
\text { at harvest }\end{array}$ \\
\hline 21 & 32.88 & 56.67 & 110.00 & 38.33 & 71.67 & 200.83 & 4.44 & 51.00 & 60.58 & 62.57 \\
\hline 41 & 29.70 & 55.33 & 135.00 & 65.00 & 70.00 & 196.47 & 5.31 & 45.00 & 53.53 & 53.77 \\
\hline 50 & 34.34 & 55.00 & 120.00 & 45.00 & 75.00 & 202.44 & 5.34 & 57.00 & 49.08 & 50.79 \\
\hline 195 & 32.53 & 50.00 & 133.33 & 51.67 & 81.67 & 133.52 & 5.40 & 49.00 & 53.53 & 54.51 \\
\hline 210 & 21.18 & 50.00 & 101.67 & 35.00 & 66.67 & 82.43 & 5.63 & 60.67 & 55.00 & 55.26 \\
\hline Average & 30.13 & 53.40 & 120.00 & 47.00 & 73.00 & 163.14 & 5.23 & 52.53 & 54.34 & 55.38 \\
\hline M-P & 25.67 & 54.50 & 121.67 & 36.67 & 85.00 & 108.78 & 5.06 & 57.00 & 54.41 & 56.68 \\
\hline GA-MP\% & $17.38 * *$ & $-2.02 * *$ & -1.37 & $28.18^{* *}$ & $-14.12 * *$ & $49.98 * *$ & $3.31 * *$ & $-7.84 * *$ & $-0.12 * *$ & $-2.29 * *$ \\
\hline $\mathrm{GA}-\mathrm{BP} \%$ & 3.25 & $-1.11 * *$ & -10.00 & $56.67 * *$ & $-18.89 * *$ & 0.50 & $-9.49 * *$ & $-13.88 * *$ & $10.72 * *$ & $9.04 * *$ \\
\hline Shandaweel 3 & 22.15 & 55.00 & 133.33 & 43.33 & 90.00 & 162.33 & 5.77 & 53.00 & 49.08 & 50.79 \\
\hline Introduction 688 & 29.18 & 54.00 & 110.00 & 30.00 & 80.00 & 55.22 & 4.34 & 61.00 & 59.74 & 62.57 \\
\hline MP LSD0.05\% & 4.45 & 0.45 & 9.26 & 8.12 & 9.95 & 20.07 & 0.10 & 0.46 & 0.07 & 0.10 \\
\hline MP LSD0.01\% & 6.24 & 0.64 & 12.98 & 11.39 & 13.94 & 28.14 & 0.14 & 0.64 & 0.10 & 0.14 \\
\hline BP LSD0.05\% & 5.14 & 0.53 & 10.69 & 9.38 & 11.48 & 23.17 & 0.11 & 0.53 & 0.08 & 0.11 \\
\hline BP LSD0.01\% & 7.21 & 0.74 & 14.99 & 13.15 & 16.10 & 32.49 & 0.16 & 0.74 & 0.11 & 0.16 \\
\hline
\end{tabular}

*,**, significant at 0.05 and 0.01 levels of probability; respectively. 
Table 8. Selected family means for seed oil $\%$ and correlated traits in the $\mathrm{F}_{5}$-generation, observed gain from mid-parent (GA$\mathrm{MP} \%$ ) and better parent (GA-BP\%).

Fam. No. Sel.criterion Correlated traits

\begin{tabular}{|c|c|c|c|c|c|c|c|c|c|c|}
\hline & Oil\% & $50 \%$ flow & $\mathrm{PH}, \mathrm{cm}$ & $\begin{array}{r}\mathrm{HFC}, \\
\mathrm{cm} \\
\end{array}$ & $\begin{array}{r}\text { LFZ, } \\
\mathrm{cm} \\
\end{array}$ & $\mathrm{NC} / \mathrm{P}$ & $\mathrm{SY} / \mathrm{P}, \mathrm{g}$ & $1000 \mathrm{SW}$ & $\begin{array}{r}\text { INF \% } \\
\text { Seedling } \\
\end{array}$ & $\begin{array}{r}\text { INF\% at } \\
\text { harvest }\end{array}$ \\
\hline 5 & 65.00 & 55.00 & 141.67 & 45.00 & 96.67 & 74.95 & 12.51 & 5.33 & 64.97 & 69.31 \\
\hline 46 & 65.00 & 59.00 & 126.67 & 45.00 & 81.67 & 161.49 & 35.54 & 5.87 & 62.28 & 62.57 \\
\hline 168 & 62.00 & 58.33 & 100.00 & 36.67 & 63.33 & 73.67 & 22.18 & 4.67 & 57.34 & 59.19 \\
\hline 185 & 60.33 & 56.33 & 133.33 & 45.00 & 88.33 & 65.71 & 22.71 & 5.23 & 65.94 & 66.25 \\
\hline 327 & 61.33 & 56.33 & 135.00 & 51.67 & 83.33 & 144.44 & 32.25 & 5.84 & 58.12 & 60.03 \\
\hline Average & 62.73 & 57.00 & 127.33 & 44.67 & 82.67 & 104.05 & 25.04 & 5.39 & 61.73 & 63.47 \\
\hline M-P & 57.00 & 54.50 & 121.67 & 36.67 & 85.00 & 108.78 & 25.67 & 5.06 & 54.41 & 56.68 \\
\hline GA-MP\% & $10.06^{* *}$ & $4.59^{* *}$ & 4.66 & $21.82^{* *}$ & -2.75 & -4.34 & -2.44 & $6.56^{* *}$ & $13.45^{* * *}$ & $11.98^{* *}$ \\
\hline GA-BP\% & $2.84^{* *}$ & $5.56^{* *}$ & -4.50 & $48.89^{* *}$ & -8.15 & $-35.90^{* *}$ & $-14.18^{* *}$ & $-6.64^{* *}$ & $25.77^{* *}$ & $24.97^{* *}$ \\
\hline Shandaweel 3 & 53.00 & 55.00 & 133.33 & 43.33 & 90.00 & 162.33 & 22.15 & 5.77 & 49.08 & 50.79 \\
\hline Introduction 688 & 61.00 & 54.00 & 110.00 & 30.00 & 80.00 & 55.22 & 29.18 & 4.34 & 59.74 & 62.57 \\
\hline MP LSD0.05\% & 0.73 & 0.48 & 8.52 & 5.66 & 9.23 & 16.43 & 7.48 & 0.11 & 0.08 & 0.17 \\
\hline MP LSD0.01\% & 1.02 & 0.67 & 11.94 & 7.94 & 12.95 & 23.03 & 10.48 & 0.16 & 0.12 & 0.24 \\
\hline BP LSD0.05\% & 0.84 & 0.55 & 9.84 & 6.54 & 10.66 & 18.97 & 8.63 & 0.13 & 0.10 & 0.20 \\
\hline BP LSD0.01\% & 1.18 & 0.77 & 13.79 & 9.16 & 14.95 & 26.59 & 12.11 & 0.18 & 0.14 & 0.27 \\
\hline
\end{tabular}

\subsubsection{Means and direct observed genetic gain in seed oil\% restricted by $S Y / P$}

Mean oil\% of the selected families (Table 9) ranged from 59.67 to $65.00 \%$ with an average of $61.13 \%$, and SY/P ranged from 20.84 to $35.54 \mathrm{~g} / \mathrm{P}$ with an average of $26.58 \%$. It could be noticed the homogeneity of the selected families in oil\% after two cycles of selection. After two cycles of pedigree selection for oil\% restricted by seed yield the observed direct genetic gains in oil \% were $7.25 \%^{* *}$, and $0.22 \%$, and in SY/P were $19.02 \%^{* *}$, and $2.85 \%$ from mid- and better parent, respectively. Significant $(\mathrm{p} \leq 0.05$ or $\mathrm{p} \leq 0.01$ ) correlated gains of $16.71^{* *}$ and $6.50 \%{ }^{* *}$

\subsubsection{Means and direct observed gain in LFZ}

Mean LFZ of the selected families (Table 10) ranged from 88.38 to $106.67 \mathrm{~cm}$ with an average of $98.67 \mathrm{~cm}$. After two cycles of pedigree selection for LFZ, the observed direct genetic gain in LFZ was $16.78 \%{ }^{* *}$ and $9.36 \%$ from the mid and better parent, respectively. The observed genetic gain in percentage of the midparent was favorable for $\mathrm{PH}\left(20.27^{* *}\right), \mathrm{NC} / \mathrm{P}$ $\left(50.09^{* *}\right), \mathrm{SY} / \mathrm{P}\left(14.05^{* *}\right)$, and $1000 \mathrm{SW}\left(6.86^{* *}\right)$, while it was unfavorable for $50 \%$ flowering $\left(0.55^{* *}\right)$, oil\% $\left(-10.16^{* *}\right)$ and infection\% at harvest $\left(5.27^{* *}\right)$. for $\mathrm{PH}, 39.09^{* *}$ and $70.0 \%^{* *}$ for HFC, $6.08^{* *}$ and $-7.06 \%^{* *}$ for $1000 \mathrm{SW}, 9.01^{* *}$ and $4.60 \%{ }^{* *}$ for CL and $3.93^{* *}$ and $15.21 \%{ }^{* *}$ for infection $\%$ at seedling stage from both the mid- and better parent, respectively. It should be indicated that selection for oil\% only (Table 8 ) insignificantly decrease LFZ, SY/P and NC/P, however, selection for oil\% restricted by SY/P significantly increased SY/P (Table 9). These results are in line with those reported by Singh $e t$ al. (2018) who estimated expected genetic advance in seed oil\% of $12.81 \%$. Mohanty et al. (2020) estimated expected genetic from the mean for oil\% of $31.50 \%$.

\subsubsection{Means and direct observed genetic gain in $\mathrm{LFZ}$ restricted by $\mathrm{HFC}$}

Mean LFZ of the selected families ranged from 75.0 to $110.00 \mathrm{~cm}$ with an average of $95.67 \mathrm{~cm}$, and from 30.00 to $43.33 \mathrm{~cm}$ with an average of $38.00 \mathrm{~cm}$ for HFC (Table 11). The direct observed genetic gain from the mid-parent for LFZ was $12.549 \%^{* *}$ and from the better parent was $6.29 \%$. Otherwise, the observed gain in HFC was not significant. Selection for LFZ restricted by HFC accompanied by favorable increase from the mid-parent in $\mathrm{PH}\left(9.86 \%{ }^{*}\right)$, NC/P $\left(58.89 \%^{* *}\right)$, SY/P $\left(19.35 \%^{* *}\right)$, and 1000- 
SW $\left(1.46 \%^{* *}\right)$. However, unfavorable genetic correlated gains were obtained for $50 \%$ flowering $\left(2.395^{* *}\right)$, oil $\%\left(-3.63 \%{ }^{*}\right)$ and infection\% at harvest $\left(8.38 \%{ }^{* * *}\right)$. Results proved the efficiency of single trait selection in changing the mean of the selection criterion, and adversely affected some correlated traits. It is of interest to indicate that selection for LFZ restricted by HFC was better in improving yield and NC/P than selection for LFZ per se. Otherwise; single trait selection for LFZ was more efficient in changing the mean of the selection criterion.

Table 9. Selected family means for seed oil\% restricted seed yield/ plant and correlated traits in the $\mathrm{F}_{5}$-generation, observed gain from the mid-parent (GA-MP\%) and better parent (GA-BP\%) under artificial infection by Fusarium oxysporum.

\begin{tabular}{|c|c|c|c|c|c|c|c|c|c|c|}
\hline \multirow[b]{2}{*}{ Fam. No. } & \multicolumn{2}{|c|}{ Selection crieriteria } & \multicolumn{8}{|c|}{ Correlated traits } \\
\hline & OIL\% & $\mathrm{SY} / \mathrm{P}, \mathrm{g}$ & $50 \%$ flow & $\mathrm{PH}, \mathrm{cm}$ & $\mathrm{HFC}, \mathrm{cm}$ & LFZ, cm & $\mathrm{NC} / \mathrm{P}$ & $\begin{array}{c}1000 \\
\text { SW }\end{array}$ & $\begin{array}{c}\text { INF \% } \\
\text { Seedling }\end{array}$ & $\begin{array}{l}\text { INF\% at } \\
\text { harvest }\end{array}$ \\
\hline 46 & 65.000 & 35.543 & 59.000 & 126.667 & 45.000 & 81.667 & 161.487 & 5.873 & 62.280 & 62.567 \\
\hline 73 & 59.667 & 20.913 & 57.000 & 143.333 & 36.667 & 106.667 & 110.037 & 5.753 & 55.773 & 56.813 \\
\hline 125 & 60.000 & 29.870 & 58.000 & 156.667 & 55.000 & 101.667 & 76.562 & 5.530 & 49.817 & 50.050 \\
\hline 252 & 60.667 & 20.843 & 57.000 & 135.000 & 58.333 & 76.667 & 88.444 & 4.463 & 60.580 & 60.850 \\
\hline 270 & 60.333 & 25.723 & 55.000 & 148.333 & 60.000 & 88.333 & 151.806 & 5.208 & 54.270 & 54.513 \\
\hline Average & 61.133 & 26.579 & 57.200 & 142.000 & 51.000 & 91.000 & 117.667 & 5.366 & 56.544 & 56.959 \\
\hline M-P & 57.000 & 22.332 & 54.500 & 121.667 & 36.667 & 85.000 & 108.778 & 5.058 & 54.408 & 56.678 \\
\hline GA-MP $\%$ & $7.251^{* *}$ & $19.018 * *$ & $4.954^{* *}$ & $16.712 * *$ & $39.091 * *$ & 7.059 & $8.172 * *$ & $6.076^{* *}$ & $3.925 * *$ & $0.495^{* *}$ \\
\hline GA-BP\% & 0.219 & 2.845 & $5.926^{* *}$ & 6.500 & $70.000 * *$ & 1.111 & $-27.515^{*}$ & $-7.061 * *$ & $15.208^{* * *}$ & $12.145^{* *}$ \\
\hline Shandaweel 3 & 53.000 & 18.820 & 55.000 & 133.333 & 43.333 & 90.000 & 162.333 & 5.773 & 49.080 & 50.790 \\
\hline Introduction 688 & 61.000 & 25.843 & 54.000 & 110.000 & 30.000 & 80.000 & 55.222 & 4.343 & 59.737 & 62.567 \\
\hline MP LSD0.05\% & 0.513 & 6.368 & 0.336 & 9.608 & 6.022 & 10.203 & 20.302 & 0.084 & 0.067 & 0.112 \\
\hline MP LSD0.01\% & 0.720 & 8.928 & 0.471 & 13.471 & 8.444 & 14.305 & 28.463 & 0.118 & 0.094 & 0.156 \\
\hline BP LSD0.05\% & 0.593 & 7.353 & 0.388 & 11.094 & 6.954 & 11.781 & 23.442 & 0.097 & 0.078 & 0.129 \\
\hline BP LSD0.01\% & 0.831 & 10.309 & 0.544 & 15.555 & 9.750 & 16.518 & 32.866 & 0.137 & 0.109 & 0.181 \\
\hline
\end{tabular}

**, significant at 0.01 levels of probability.

3.2.8. Means and direct observed gain in 1000seed weight

Mean 1000-SW of the selected families (Table 12) ranged from 5.31 to $5.50 \mathrm{~g}$ with an average of $5.39 \mathrm{~g}$. After two cycles of pedigree selection for $1000 \mathrm{SW}$ the observed direct genetic gain in $1000 \mathrm{SW}$ was $18.14^{* *}$, and $12.82 \%^{* * *}$ from the mid- and better parent, respectively, accompanied by observed correlated gain of $14.25^{*}$ and $4.25 \% \%$ for $\mathrm{PH}, 3.61^{* *}$ and $4.57^{* *}$ in $50 \%$ flowering, $53.64^{* *}$ and $87.78 \%{ }^{* *}$ for HFC,
-2.75 and -8.15 for LFZ, 52.24 $4^{* *}$, and 2.02 for $\mathrm{NC} / \mathrm{P}, 14.09^{* *}$ and $0.36^{* *}$ for SY/P, 2.07**, $1.29^{* *}$ and $\quad-5.36^{* *}$ for oil $\%$ and $9.32^{* *}$ and $21.99 \%$ ** for infection $\%$ at harvest from the mid and better parent, respectively. Mohanty et al., 2020 reported high to moderate phenotypic and genotypic coefficients of variation accompanied by high heritability and high to moderate genetic advance in percentage of the mean for 1000 seed weight, oil content $\%$, oil yield/plant and seed yield/ plant. 
Table 10. Selected family means for length of the fruiting zone and correlated traits in the $\mathrm{F}_{5}$-generation, observed gain from the mid-parent (GA-MP\%) and better parent (GA-BP\%).

\begin{tabular}{|c|c|c|c|c|c|c|c|c|c|c|}
\hline \multirow[b]{2}{*}{ Fam. No. } & \multirow{2}{*}{$\begin{array}{c}\text { Sel. } \\
\text { criterion } \\
\text { LFZ, cm }\end{array}$} & \multicolumn{9}{|c|}{ Correlated traits } \\
\hline & & $\mathrm{HFC}, \mathrm{cm}$ & DFF & $\mathrm{PH}, \mathrm{cm}$ & $\mathrm{NC} / \mathrm{P}$ & $\mathrm{SY} / \mathrm{P}, \mathrm{g}$ & $\begin{array}{l}1000 \\
\text { SW }\end{array}$ & OIL\% & $\begin{array}{c}\text { INF \% } \\
\text { Seedling }\end{array}$ & $\begin{array}{c}\text { INF\% } \\
\text { at } \\
\text { harvest }\end{array}$ \\
\hline 72 & 88.33 & 41.67 & 55.33 & 130.00 & 83.690 & 13.653 & 5.88 & 64.00 & 59.74 & 60.85 \\
\hline 152 & 101.67 & 61.67 & 50.00 & 163.33 & 144.333 & 16.147 & 5.35 & 52.00 & 61.41 & 62.57 \\
\hline 183 & 108.33 & 65.00 & 57.33 & 173.33 & 192.395 & 30.080 & 4.91 & 48.00 & 61.41 & 61.71 \\
\hline 239 & 88.33 & 40.00 & 56.33 & 128.33 & 165.043 & 34.260 & 5.70 & 55.00 & 51.28 & 51.49 \\
\hline 281 & 106.67 & 30.00 & 55.00 & 136.67 & 230.909 & 52.213 & 5.18 & 55.00 & 58.93 & 61.71 \\
\hline Average & 98.667 & 47.667 & 54.80 & 146.333 & 163.274 & 29.27 & 5.40 & 54.80 & 58.55 & 59.67 \\
\hline M-P & 85.000 & 36.667 & 54.50 & 121.667 & 108.778 & 25.67 & 5.06 & 57.00 & 54.41 & 56.68 \\
\hline GA-MP\% & $16.078^{* *}$ & $30.000^{* *}$ & $0.55^{*}$ & $20.274^{* *}$ & $50.099^{* *}$ & $14.05^{* *}$ & $6.82^{* *}$ & $-3.86^{* *}$ & $7.62^{* *}$ & $5.27^{* *}$ \\
\hline GA-BP\% & $9.630^{* * *}$ & $58.889^{* * *}$ & $1.48^{* *}$ & 9.750 & 0.580 & 0.32 & $-6.41^{* *}$ & $-10.16^{* *}$ & $19.30^{* *}$ & $17.48^{* *}$ \\
\hline Shandaweel 3 & 90.00 & 43.33 & 55.00 & 133.33 & 162.333 & 22.153 & 5.77 & 53.00 & 49.08 & 50.79 \\
\hline Introduction 688 & 80.00 & 30.00 & 54.00 & 110.00 & 55.222 & 29.177 & 4.34 & 61.00 & 59.74 & 62.57 \\
\hline MP LSD0.05\% & 13.255 & 7.099 & 0.48 & 10.476 & 29.346 & 5.63 & 0.10 & 0.91 & 0.04 & 0.12 \\
\hline MP LSD0.01\% & 18.584 & 9.953 & 0.67 & 14.688 & 41.143 & 7.89 & 0.14 & 1.28 & 0.06 & 0.16 \\
\hline BP LSD0.05\% & 15.306 & 8.198 & 0.55 & 12.097 & 33.886 & 6.50 & 0.11 & 1.05 & 0.05 & 0.14 \\
\hline BP LSD0.01\% & 21.459 & 11.493 & 0.77 & 16.960 & 47.508 & 9.11 & 0.16 & 1.47 & 0.07 & 0.19 \\
\hline
\end{tabular}

3.3. Comparison between the eight selection methods under artificial infection of $F$. oxysporum

Two cycles of selection for days to $50 \%$ flowering (Table 13) improved earliness from the mid-parent $\left(-7.77^{* *}\right)$ and $-6.91^{* *}$ from the better-parent followed by improve in the correlated traits in percentage of mid-parent; $\mathrm{PH}$ $\left(16.99^{* *}\right), \mathrm{SY} / \mathrm{P}(19.32), 1000 \mathrm{SW}\left(7.47^{* *}\right)$, and favorable decrease in INF\% at harvest $\left(-1.78^{* *}\right)$. This could be due to negative correlation between these traits and days to $50 \%$ flowering in the base population (Table 2). However, negative decrease from the mid-parent was obtained in oil\% $\left(-6.08^{* *}\right)$.

Selection for days to $50 \%$ flowering restricted by SY/P, reduced days to $50 \%$ flowering ($5.93^{* * *}$ ) and increase SY/P $\left(35.56 \%^{* *}\right)$ compared to selection for days to $50 \%$ flowering per se.
Mostly, all the characters showed positive correlation with SY/P in the base population were improved. The correlated gains measured in percentage from the mid-parent were $14.25^{* *}$ (PH), 44.55 ${ }^{* *}$ (HFC), 1000-SW (4.54**), and $84.69^{* * *}(\mathrm{NC} / \mathrm{P})$. Otherwise, negative reduction was obtained in oil\% $\left(-4.68^{* *}\right)$. This means that single trait selection proved to be an efficient method in improving selection criterion, and the incorporation of valuable traits with the selection criterion improved genetic correlated gains. (Mahdy et al., 2015a,b) stated that pedigree selection is an efficient method to improve selection criterion and improved the direct observed gain in days to first flower by 35.31 and $-34.06 \%$ in pop1, and 37.18 and $9.75 \%$ in pop 2 from the unselected bulk sample and the better parent, respectively. The direct observed genetic gain from selection for SY/P 
was positive from the mid-parent $\left(17.38 \%^{* * *}\right)$. The observed correlated gain in percentage of the mid-parent was favorable in days to $50 \%$ flowering $\left(-2.02 \%^{* *}\right), 49.98^{* *}$ in $\mathrm{NC} / \mathrm{P}, 3.31^{* *}$ in $1000-\mathrm{SW}, 4.04^{* *}$ in CL, and -2.29 in Inf $\%$ at harvest. The other correlated gains in HFC, LFZ, $\mathrm{CW}$, and oil\% were unfavorable. Mahdy et al. (2015a) improved SY/P throw two cycles of selection by 30.68 and $45.18 \%$ from the better parent in two populations.

Table 11. Selected family means for length of the fruiting zone restricted by HFC and correlated traits in the $\mathrm{F}_{5}$-generation, observed gain from the mid-parent (GA-MP\%) and better parent (GA-BP\%).

\begin{tabular}{|c|c|c|c|c|c|c|c|c|c|c|}
\hline \multirow[b]{2}{*}{ Fam. No. } & \multirow{2}{*}{$\begin{array}{c}\text { Sel.criterion } \\
\text { LFZ, cm }\end{array}$} & \multicolumn{9}{|c|}{ Correlated traits } \\
\hline & & DFF & $\mathrm{PH}, \mathrm{cm}$ & $\mathrm{HFC}, \mathrm{cm}$ & $\mathrm{NC} / \mathrm{P}$ & $\mathrm{SY} / \mathrm{P}, \mathrm{g}$ & 1000SW & OIL \% & $\begin{array}{c}\text { INF \% } \\
\text { Seedling }\end{array}$ & $\begin{array}{l}\text { INF\% } \\
\text { at } \\
\text { harvest }\end{array}$ \\
\hline 89 & 75.00 & 53.00 & 115.00 & 40.00 & 136.31 & 21.28 & 5.30 & 57.33 & 54.27 & 57.59 \\
\hline 184 & 80.00 & 58.00 & 126.67 & 46.67 & 151.33 & 24.82 & 4.95 & 56.33 & 55.77 & 58.40 \\
\hline 271 & 110.00 & 55.00 & 140.00 & 30.00 & 232.13 & 47.14 & 5.35 & 56.33 & 67.92 & 74.18 \\
\hline 281 & 106.67 & 55.00 & 136.67 & 30.00 & 230.91 & 36.88 & 5.18 & 55.00 & 58.93 & 61.71 \\
\hline 347 & 106.67 & 58.00 & 150.00 & 43.33 & 113.50 & 23.26 & 4.87 & 49.67 & 55.00 & 55.26 \\
\hline Average & 95.667 & 55.80 & 133.667 & 38.000 & 172.84 & 30.68 & 5.13 & 54.93 & 58.38 & 61.43 \\
\hline M-P & 85.000 & 54.50 & 121.667 & 36.667 & 108.78 & 25.67 & 5.06 & 57.00 & 54.41 & 56.68 \\
\hline GA-MP\% & $12.549^{*}$ & $2.39^{* *}$ & $9.863^{*}$ & 3.636 & $58.89^{* * *}$ & $19.53 * *$ & $1.46^{* *}$ & $-3.63^{* *}$ & $7.30^{* *}$ & $8.38^{* *}$ \\
\hline GA-BP\% & 6.296 & $3.33^{* *}$ & 0.250 & $26.667^{* *}$ & 6.47 & 5.15 & $-11.11^{* *}$ & $-9.95^{* *}$ & $18.95^{* * *}$ & $20.94^{* *}$ \\
\hline Shandaweel 3 & 90.00 & 55.00 & 133.33 & 43.33 & 162.33 & 22.15 & 5.77 & 53.00 & 49.08 & 50.79 \\
\hline Introduction 688 & 80.00 & 54.00 & 110.00 & 30.00 & 55.22 & 29.18 & 4.34 & 61.00 & 59.74 & 62.57 \\
\hline MP LSD0.05\% & 11.236 & 0.43 & 8.949 & 7.673 & 17.83 & 5.51 & 0.10 & 0.75 & 0.12 & 0.34 \\
\hline MP LSD0.01\% & 15.752 & 0.61 & 12.546 & 10.758 & 25.00 & 7.73 & 0.14 & 1.05 & 0.17 & 0.48 \\
\hline BP LSD0.05\% & 12.974 & 0.50 & 10.333 & 8.860 & 20.59 & 6.37 & 0.11 & 0.87 & 0.14 & 0.39 \\
\hline BP LSD0.01\% & 18.189 & 0.70 & 14.487 & 12.422 & 28.87 & 8.92 & 0.16 & 1.22 & 0.19 & 0.55 \\
\hline
\end{tabular}

$*, * *$, significant at 0.05 and 0.01 levels of probability; respectively.

The direct observed genetic gain from selection for oil\% was positive from both of mid-parent $\left(10.06 \%^{* *}\right)$ and better parent $\left(2.84 \%^{* * *}\right)$. The observed correlated gain from the mid-parent was unfavorable for SY/P (-2.44), days to50\% flowering $\left(4.59^{* * *}\right)$, HFC $\left(21.82^{* *}\right)$, infection $\%$ at seedling stage $\left(13.45^{* *}\right)$ and infection\% at harvest $\left(11.98 \%^{* *}\right)$, and favorable in $1000 \mathrm{SW}$ $\left(6.56 \%^{* *}\right)$.

Selection for oil\% restricted by SY/P gave direct observed genetic gain from the mid-parent of $7.25 \%^{* *}$ (lower than selection for oil\% per se), and $19.02 \%^{* *}$ for SY/P. Favorable correlated gains were obtained in $\mathrm{PH}\left(16.71 \%^{* *}\right), \mathrm{NC} / \mathrm{P}$ $\left(8.17 \%^{* *}\right)$, and $1000 \mathrm{SW}\left(6.08 \%^{* *}\right)$. The other correlated traits, days to $50 \%$ flowering, HFC, and INF\% showed unfavorable gains. Inclusion of SY/P with oil\% in selection increased SY/P, $1000 \mathrm{SW}$, and NC/P. Selection for LFZ gave direct observed genetic gain from the midparent of $16.08 \%^{* * *}$ and $9.63 \%^{* *}$ from the better parent. Favorable correlated gains from the midparent were obtained in $\mathrm{PH}\left(20.27 \%^{* *}\right), \mathrm{NC} / \mathrm{P}$ $\left(50.10 \%^{* *}\right), \mathrm{SY} / \mathrm{P}\left(14.05 \%^{* *}\right)$ and $1000 \mathrm{SW}$ $\left(6.82 \%^{* *}\right)$. The other correlated traits gave unfavorable gains from selection. 
Table 12. Selected family means for 1000 -seed weight in the $\mathrm{F}_{5}$-generation, observed gain from the mid-parent (GA-MP\%) and better parent (GA-BP\%).

\begin{tabular}{ccccccccccc}
\hline & Sel.crit. & & & \multicolumn{7}{c}{ Correlated traits } \\
Fam. No. & $\begin{array}{c}\text { 1000S } \\
\text { W, g }\end{array}$ & $\begin{array}{c}50 \% \\
\text { flow }\end{array}$ & PH, cm & $\begin{array}{c}\text { HFC, } \\
\mathrm{cm}\end{array}$ & $\begin{array}{c}\text { LFZ; } \\
\mathrm{cm}\end{array}$ & NC/P & SY/P, g & OIL\% & $\begin{array}{c}\text { INF \% } \\
\text { Seedling }\end{array}$ & $\begin{array}{c}\text { INF\% at } \\
\text { harvest }\end{array}$ \\
\hline 5 & 5.33 & 55.00 & 141.67 & 45.00 & 96.67 & 74.95 & 12.51 & 65.00 & 64.97 & 69.31 \\
24 & 5.40 & 56.33 & 115.00 & 55.00 & 60.00 & 272.46 & 46.49 & 60.33 & 60.58 & 62.57 \\
125 & 5.53 & 58.00 & 156.67 & 55.00 & 101.67 & 76.56 & 29.87 & 60.00 & 49.82 & 50.05 \\
127 & 5.31 & 63.00 & 118.33 & 65.00 & 53.33 & 259.72 & 38.05 & 51.33 & 64.07 & 65.31 \\
152 & 5.35 & 50.00 & 163.33 & 61.67 & 101.67 & 144.33 & 19.48 & 52.00 & 61.41 & 62.57 \\
Average & 5.39 & 56.47 & 139.00 & 56.33 & 82.67 & 165.60 & 29.28 & 57.73 & 60.17 & 61.96 \\
M-P & 4.56 & 54.50 & 121.67 & 36.67 & 85.00 & 108.78 & 25.67 & 57.00 & 54.41 & 56.68 \\
GA-MP\% & $18.14 * *$ & $3.61 * *$ & $14.25 *$ & 53.64 & -2.75 & $52.24 * *$ & $14.09 * *$ & $1.29 * *$ & $10.59 * *$ & $9.32 * *$ \\
GA-BP\% & $12.82 * *$ & $4.57 * *$ & 4.25 & 87.78 & -8.15 & 2.02 & 0.36 & $-5.36 * *$ & $22.59 * *$ & $21.99 * *$ \\
Shandaweel 3 & 4.77 & 55.00 & 133.33 & 43.33 & 90.00 & 162.33 & 22.15 & 53.00 & 49.08 & 50.79 \\
Introduction & & & & & & & & & & \\
688 & 4.34 & 54.00 & 110.00 & 30.00 & 80.00 & 55.22 & 29.18 & 61.00 & 59.74 & 62.57 \\
MP LSD0.05\% & 0.10 & 1.01 & 11.11 & 5.78 & 13.24 & 22.21 & 6.64 & 0.87 & 0.07 & 0.17 \\
MP LSD0.01\% & 0.14 & 1.41 & 15.58 & 8.11 & 18.56 & 31.14 & 9.31 & 1.22 & 0.10 & 0.24 \\
BP LSD0.05\% & 0.12 & 1.16 & 12.83 & 6.68 & 15.29 & 25.65 & 7.67 & 1.00 & 0.08 & 0.20 \\
BP LSD0.01\% & 0.17 & 1.63 & 17.99 & 9.36 & 21.43 & 35.96 & 10.75 & 1.41 & 0.11 & 0.28 \\
\hline
\end{tabular}

$*, * *$, significant at 0.05 and 0.01 levels of probability; respectively.

Selection for LFZ restricted by HFC increased LFZ $\left(12.55 \%^{* *}\right)$ and SY/P $\left(19.53 \%^{* * *}\right)$ from the mid-parent, followed by favorable increase in $\mathrm{NC} / \mathrm{P}, 1000-\mathrm{SW}, \mathrm{Cl}$, and CW. Selection for LFZ only was less efficient than selection for LFZ restricted by HFC in improving correlated traits. Direct selection for 1000 SW increased seed weight $\left(18.14 \%^{* * *}\right)$ and gave sizeable favorable correlated gains from the mid-parent in SY/P $\left(14.08 \%^{* *}\right), \mathrm{PH}\left(14.25 \%^{* *}\right), \mathrm{NC} / \mathrm{P}\left(52.24 \%^{* *}\right)$. The other correlated traits were adversely affected. ( Ismail et al., 2014) improved SY/P by $46.68 \%$ of the better parent after two cycles of selection. (Mahdy et al., 2015a) noted direct observed gain after two cycles of selection of 56.71 and $-56.17 \%$ for height to first capsule, 43.21 and $81.52 \%$ for number of capsules/plant and 30.68 and $45.18 \%$ for seed yield from the better parent for population 1 and 2; respectively. Mahdy et al., 2015b found significant $(\mathrm{p} \leq 0.01)$ observed gain in days to first flower of -35.31 and $-34.06 \%$ in pop1, and 37.18 and $-9.75 \%$ in pop 2 from the unselected bulk sample and the better parent; respectively after two cycles of selection. 
Table 13. Means of the selected families, observed gain from the mid-parent (GA-MP\%) and better parent (GA-BP\%) for the eight selection criteria in the $\mathrm{F}_{5^{-}}$generation under artificial infection by Fusarium oxysporum.

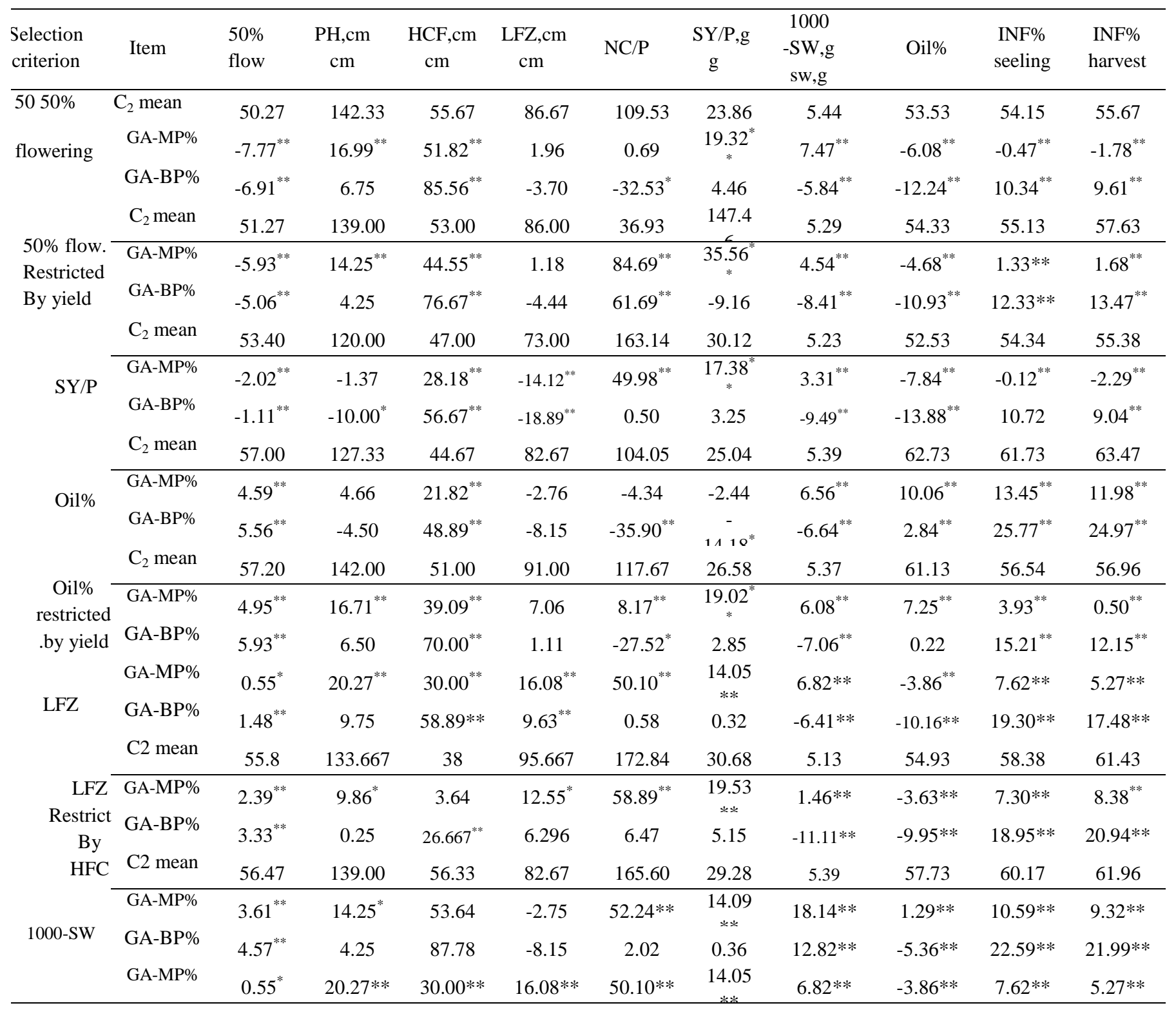

\section{Conclusion}

Single trait selection was an efficient method to improve selection criterion, but it caused adverse effects on some correlated traits. Selection for days to $50 \%$ flowering improved earliness, but it was better in improving yield if it restricted by SY/P.

Selection for oil\% restricted by yield was better in improving yield than selection for oil\% pe se.
Inclusion of a trait as independent culling level improves the efficiency of selection. Therefore, selection index incorporating favorable trait is recommended. The correlation coefficients among traits help the breeder to select for few favorable traits. The best genetic gain in SY/P in percentage from the mid-parent was obtained from selection for days to $50 \%$ flowering restricted by SY/P $\left(35.56^{* *}\right)$ [because of the negative genotypic correlation between 
them), LFZ restricted by HFC $\left(19.53^{* *}\right)$, days to $50 \%$ flowering $\left(19.32^{* * *}\right)$, oil\% restricted by SY/P $\left(19.02^{* *}\right), \mathrm{SY} / \mathrm{P}\left(17.38^{* *}\right)$, $1000-\mathrm{SW}\left(14.09^{* *}\right)$ and LFZ $\left(14.032^{* *}\right)$.

\section{References}

Aladji, M. A., Noubissie, J. T. and Njitang, N. Y. (2014) 'Genetic Analysis of Seed Yield Components in Sesame ( Sesamum indicum L .) at', Scholars Academic Journal of Biosciences (SAJB), 2(5), pp. 318-325.

Abdul Wahid, O.A and Elbaramawy, M.A.E. (2007) 'Resistance of some sesame [Sesamum indicum L.] collections against root rot disease [Rhizoctonia solani Kuhn] under field conditions', Journal of Plant Protection Research, 47(3), pp. 321-328. Available at: http://yadda.icm.edu.pl/yadda/element/bw meta1.element.agro-article-b68df89b0adf-4cc5-a7b9-ef2909126b8e.

Ashri, A. (1994) 'Genetic resources of sesame: present and future perspective', in.

Ashri, A. (2010) 'Sesame Breeding', in Plant Breeding Reviews. Oxford, UK: John Wiley \& Sons, Inc., pp. 179-228. doi: 10.1002/9780470650110.ch5.

Baydar, H., Marquard, R. and Turgut, I. (1999) 'Pure line selection for improved yield, oil content and different fatty acid composition of sesame, Sesamum indicum', Plant Breeding, 118(5), pp. 462-464. doi: 10.1046/j.1439-0523.1999.00414.x.

Bedigian, D., and Harlan J.R. (1986) 'Evidence for cultivation of sesame in the ancient world'. Econ. Bot. 40: 137-154.

Bharat Patidar, Dileep Tripathi, Siddharth Patidar, M. P. and G. K. (2020) 'The association and path coefficient analysis for yield and yield attributing traits in sesame (Sesamum indicum L.)', Journal of Pharmacognosy and Phytochemistry, 9(3), pp. 1674-1678.
Bharathi, D., Rao, V. T., Mohan, Y. and Bhadru, D. (2014) 'Genetic variability studies in sesame (Sesamum indicum L.)', International Journal of Applied Biology and Pharmaceutical Technology, 5(4), pp. 31-33.

Booth, C. (1971) 'The genus Fusarium.' Commonweal.

Burton, G. W. (1952) 'Quantitative inheritance in grasses.', in Proceedings of $6^{\text {th }}$ International Grassland Congress, 1, 277283. (ed.) Quantitative inheritance in grasses.

Chung, J., Lee, J. and Choe, E. (2006) 'Oxidative Stability of Soybean and Sesame Oil Mixture during Frying of Flour Dough', Journal of Food Science, 69(7), pp. 574578. doi: 10.1111/j.13652621.2004.tb13652.x.

Disowja, A., Parameswari, C. Gnanamalar, R. P. and Vellaikumar, S. (2020) 'Evaluation of sesame (Sesamum indicum L.) based on correlation and path analysis'. Electronic Journal of Plant Breeding, 11(2), pp. 511514. Available at: http://www.ejplantbreeding.org/index.php /EJPB/article/view/3538.

Falconer, D. S. (1989) Introduction to quantitative genetics. 3rd ed. Longman, Hong Kong, pp 438.

Fazal, A., Saad, H., Mustafa, B., Anwar, M., Nadeem, M. H. and Sadaqat, H. A. (2015) 'Temperature Max Temperature Min Months', 13(5), pp. 27-32.

Iqbal, A. (2016) 'Genetic estimates and diversity study in Sesame(Sesamum indicum L.)', IOSR Journal of Agriculture and Veterinary Science, 09(08), pp. 01-05. doi: 10.9790/2380-0908010105.

Ismail, A. A., Abo-Elwafa, A., Sedeck, F.S. and Abd-Elsaber, A. (2014) 'Early and Late Pedigree Selection for Seed Yield/Plant in Sesame (Sesamum indicum L.)', Assiut J. Agric. Sci., 45(5), pp. 1-17. doi: 
10.21608/ajas.2014.3512.

Jyothi, B., Ansari, N. A., Vijay, Y., Anuradha, G., Sarkar, A., Sudhakar, R. and Siddiq, E. A. (2011) 'Assessment of resistance to Fusarium wilt disease in sesame (Sesamum indicum L.) germplasm', Australasian Plant Pathology, 40(5), pp. 471-475. doi: 10.1007/s13313-011-0070-x.

Kanak, S. and Rajani, B. (2016) 'Genetic Variability, Correlation and Path Analysis Studies for Yield and Yield Component Traits in Sesamum (Sesamum indicum L.)', International Journal of Agriculture Sciences, 8(61), pp. 61. Available at: http://www.bioinfopublication.org/jouarchi ve.php?opt=\&jouid=BPJ0000217.

Mahdy, E., Ismail, A. A., El-Shimy, A. A., Sayed, M. A. and Aya Salah (2015a) 'pedigree selection to improve seed yield in sesame', Egypt. J. Plant Breed., 19(2), pp. $337-353$.

Mahdy, E., Ismail, A. A., Shimy, A. A. E.-, Sayed, M. A. and Salah, A. (2015b) 'Pedigree selection for earliness in sesame', Egypt. J. Plant Breed., 19(2), pp. 323 336.

Mahmoud, A. F. (2016) 'Occurrence of Fusarium wilt on summer squash caused by Fusarium oxysporum in Assiut, Egypt', Journal of Phytopathology and Pest Management, 3(1), pp. 34-45.

Miller, P. A., Williams, J. C., Robinson, H. F. and Comstock, R. E. (1958) 'Estimates of Genotypic and Environmental Variances and Covariances in Upland Cotton and Their Implications in Selection 1', Agronomy Journal, 50(3), pp. 126-131. doi:

10.2134/agronj1958.000219620050000300 $04 \mathrm{x}$.

Mohanty, T. A., Singh, U. K., Singh, S. K., Kushwaha, N. and Singh, D. (2020) 'Study of Genetic Variability, Heritability and Genetic Advance in Sesame (Sesamum indicum L.) Genotypes', International Journal of Current Microbiology and Applied Sciences, 9(2), pp. 347-356. doi: 10.20546/ijcmas.2020.902.044.

Nayar, N. M. (1984) Sesame. In: Simmonds, N.W. (Ed.), Evolution of Crop Plants. In: Simmon.

Ngamba, Z. S., Tusiime, G., Gibson, P., Edema, R., Biruma, M., Masawe, P. A. L. and Kafiriti, E. (2020) 'Inheritance pattern of resistance to Fusarium wilt ( Fusarium oxysporum f . sp sesame ) in sesame', Journal of Plant Breeding and Crop Science, 12(June), pp. 175-183. doi: 10.5897/JPBCS2019.0880.

Patidar, B., Tripathi, D., Patidar, S., Patidar, M. and Kumari, G. (2020) 'The association and path coefficient analysis for yield and yield attributing traits in sesame (Sesamum indicum L.)'. Journal of Pharmacognosy and Phytochemistry, 9(3), 1674-1678.

Patil, M. K. and Lokesha, R. (2018) 'Estimation of Genetic Variability, Heritability, Genetic Advance, Correlations and Path Analysis in Advanced Mutant Breeding Lines of Sesame (Sesamum indicum L.)', Journal of Pharmacognosy \& Natural Products, 04(01), pp. 1-5. doi: 10.4172/24720992.1000151.

Rajan, S. K. A. B. (2016) 'genetic variability, correlation and path analysis studies for yield and yield component traits in sesamum (sesamum indicum 1.)', International Journal of Agriculture Sciences, 8(61), pp. 3487-3489.

Robert Jeorge Douglas Steel, James Hiram Torrie ), D. A. D. (no date) Principles and Procedures of Statistics: A Biometrical Approach. $2^{\text {nd }}$ Ed. McGraw Hill Book Company. Inc. New York, NY.

Saravanan, M., Ramachandran, K. R. and Viswanathan, P. L. (2020) 'Assessment of genetic variability, character association 
and path analysis in F2 population of $\begin{array}{lll}\text { sesame (Sesamum indicum L.)', } & \end{array}$ ELECTRONIC JOURNAL OF PLANT BREEDING, 11(02), pp. 447-450. doi: 10.37992/2020.1102.077.

Shammoro, M. H., Kebede, S. A. and Gebremichael, D. E. (2020) 'Genetic variability and multivariate analysis in indigenous and exotic sesame (Sesamum indicum L.) genotypes at Werer, Ethiopia'. International Journal of Plant Breeding and Crop Science, 7(2), 814823.

Singh, A., Bisen, R. and Tiwari, A. (2018) 'Genetic Variability and Character Association in Sesame (Sesamum indicum L.) Genotypes', International Journal of Current Microbiology and Applied Sciences, 7(11), pp. 2407-2415. doi: 10.20546/ijcmas.2018.711.274.

Smith, J. D. and Kinman, M. L. (1965) 'The Use of Parent-Offspring Regression as an Estimator of Heritability 1', Crop Science, 5(6), pp. 595-596. doi: 10.2135/cropsci1965.0011183X000500060 $035 x$.

Soundharya, B., Hemalatha, V., Rani, T. S. and Edukondalu, B. (2017) 'Sopundharrya, B.,
V. Hemalatha, T. Shobha Rani and B. Edukondalu. 2017. Trait association and path coefficient analysis for yield and yield attributing traits in sesame (Sesamum indicum. L). Environment \& Ecology, 35 (4): 3617-3620.', Environment and Ecology, 35(4E), pp. 3617-3620.

Steel, R.G.D., Torrie, J.H. and Dicky, D.A. (1997) 'Principles and Procedures of Statistics'. A Biometrical Approach'. $2^{\text {nd }}$ Ed. McGraw Hill Book Company. Inc. New York, NY.

Suja, K. P., Abraham, J. T., Thamizh, S. N., Jayalekshmy, A. and Arumughan, C. (2004) 'Antioxidant efficacy of sesame cake extract in vegetable oil protection', Food Chemistry, 84(3), pp. 393-400. doi: 10.1016/S0308-8146(03)00248-6.

Vanishree, Lokesha, R., Diwan, J. R. and Ravi, M. V. (2011) 'Study on character association and contribution of yield related traits to seed yield in segregating generation (F4 families) of sesame (Sesamum indicum L.)', Electronic Journal of Plant Breeding, 2(4), pp. 559-562.

Weiss, E. A. (1983) Oil Seed Crops. , NewYork, USA,. 